\title{
Linking into Global Value Chains Is Not Sufficient: Do You Export Domestic Value Added Contents?
}

Rashmi Banga

Unit of Economic Cooperation and Integration among Developing Countries, UNCTAD, Geneva, Switzerland

\begin{abstract}
This paper compares alternative ways of measuring participation of a country in Global Value Chains (GVCs) and estimates distribution of gains among countries in terms of countries' shares in total value-added created by trade under GVCs. Using the OECDWTO database on Trade in Value Added, this paper shows that $67 \%$ of total global value created under global value chains, accrue to OECD countries while share of NICs and BRICs countries is $25 \%$. Only $8 \%$ of total value added is shared among all other developing countries and Least Developed Countries (LDCs). Linking into Global Value Chains is not enough for taking gains. Policy should be designed to raise forward linkages, that is, exporting domestic value-added contents. Trade-led growth is more complex than it seems.
\end{abstract}

JEL Classifications: F13, F14, F62, F63

Key words: Global Value Chains, Forward Linkages, Gains in GVCs, Participation in GVCs

\footnotetext{
* Corresponding Author: Rashmi Banga; Unit of Economic Cooperation \& Integration among Developing Countries, UNCTAD, Room 9015, Palais des Nations, CH-1211 Geneva 10 Switzerland, Tel: +41 229174544, Fax: +41 229170194, Mobile:+41 786900346, Email: rashmi.banga@unctad.org, rashmibanga@yahoo.com
} 


\section{Introduction}

The trade-led-development debate has become even more complex with the Global Value Chains (GVCs). Global Value Chains have fragmented production processes across countries and boosted network trade, so linking into GVCs per se is increasingly considered as a new development challenge in developing countries. Industrial policies are being reshaped in order to adjust to this new dimension of trade and foreign direct investments, aiming to link into value chains. In this race, very little attention is being paid to measuring net value-added created by trade within GVCs. One of the probable reasons for this is the lack of conceptual clarity on what trade can be categorized as trade under GVCs and on how to measure it, let alone measuring distribution of gains under GVCs in terms of value added.

There is a growing consensus that trade data is unable to capture the net valueadded $^{1}$ gains under international fragmentation brought by GVCs, mainly because trade statistics were designed to capture trade flows in final products while the share of intermediate trade is now increasing at a faster rate and thus the trade data is often subject to double counting due to the trade of intermediate products. The splintering of many services from manufactured products and the rising share of services in trade has further limited the use of trade data. Studies have been suggesting that gains from trade should be based on net value-added by trade (Porter 1985, Kogut 1985). Likewise, comparative advantage, now must be based on activities and tasks rather than products and industries (Gereffi 1999).

Input-Output (I-O) analyses provide a useful alternative to trade data. An important advantage of I-O tables is that they classify goods according to their use as input or as final demand, making it possible for analysis to include services trade. In this regard, OECD-WTO in May 2013 released its dataset on Trade In Value-Added (TIVA) for 58 countries including all OECD countries, BRICs countries, Newly Industrialized Countries tier 1(Chinese Taipei, Korea, and Singapore), Newly Industrialized Countries tier 2(China, Hong Kong, Malaysia, Philippines, and Thailand), Cambodia, Brunei Darussalam, and the rest of the world for the years 1995, 2000, 2005, 2008, and 2009 using harmonized input-output tables of these countries. UNCTAD has extended this to

${ }^{1}$ Value-added is defined as value of output minus value of inputs. 
include developing as well as least developed countries ${ }^{2}$.

The debate has now focused on the manner in which participation in GVCs can be estimated. This brings to the forefront issues with respect to measuring trade in GVCs and the distribution of value-added gains between countries linked in GVCs.

This paper compares alternative ways of measuring the participation of a country in GVCs and estimates the distribution of gains between countries in terms of countries' shares in total value-added created under GVCs. It further shows that the implications of linking into GVCs can change drastically, especially for developing countries. The paper is organized as follows:

Section II discusses briefly the evolution of GVCs and explains the gaps between value-added exports and gross exports. It estimates value-added exports and gross exports for selected developed and developing countries to investigate foreign valueadded and domestic value-added in their exports. Section III provides different ways of estimating a country's participation in GVCs and of using the Trade In ValueAdded database provided by OECD-WTO. Section IV provides the share of different components of global gross exports in terms of foreign value-added and domestic valueadded in manufacturing and services sectors for selected countries. Section V highlights the role of services in climbing value chains. Section VI estimates the share of GVCs in the total value-added created by low-tech industries in selected countries. Sector-wise comparison of foreign value-added in the gross exports of China and India is discussed and the ratio of backward and forward linkages is estimated for selected developed and developing countries. Section VII concludes.

\section{Global Value Chains and Value-Added Trade}

Global value chains first emerged in the from of supply chains in East Asia, with Japanese investors taking the lead in the region and triggering a flying geese pattern of investments and trade. Japanese investors put up production bases in a large number of countries in East Asia and later in Southeast Asia to take locational advantages and develop export platforms for various components. The final assembly took place in a third country from where the finished products were exported, either back to the home

\footnotetext{
${ }^{2}$ This database is not yet in the public domain and therefore not been used.
} 
country or to global markets under the Japanese brand. This fragmentation of production improved the cost competitiveness. What emerged from this phenomenon were Global Value Chains (GVCs) with the production process spreading across countries, regions, and continents to become globally competitive.

GVCs played an important role in boosting network trade. World network trade increased from 988 billion US dollars that amounts to $44 \%$ of total manufacturing exports in 1990 1991, to 4.5 trillion US dollers in 2009 2010, accounting for over 60\% of the total world manufacturing exports during this period ${ }^{3}$. GVCs have increasingly been for beyond network trade ${ }^{4}$ including all the activities from research and development activities to product designing, sourcing of primary products, production of intermediate products, final assembly of the product, packaging, branding and marketing of the product. These activities are all currently being split up and undertaken in different countries. A global value chain can be understood as the sequence of all functional activities required in the process of value creation involving more than one country. ${ }^{5}$ The GVC for a particular product may therefore not only span across countries but also span across different industries, including services.

Given the above conceptual definition of GVCs, measuring gains from trade by GVCs, harmonized input-output tables of different countries are used to estimate the domestic value-added and foreign value-added created in manufacturing, as well as services sectors when a product is exported from a particular country. Domestic value-added exports will therefore differ from gross exports and can be estimated by subtracting foreign value-added. Correspondingly, global value-added exports can be arrived at by summing the domestic value-added exports of all countries. This sum nets out double counting in global trade, which is caused by the export and re-exports of intermediate products in network trade.

In 2009, world gross exports amounted to 17.05 trillion US dollars. However, world value-added exports amounted to 13.7 trillion US dollars which is around 19\% lower than gross exports. While world gross exports as a proportion of GDP increased from $19 \%$ in 1995 to $25 \%$ in 2005 and $29 \%$ in 2009 , world value added exports were much lower where it was $16 \%, 18 \%$, and $24 \%$ in 1995,2005 , and 2009 , respectively.

\footnotetext{
${ }^{3}$ Athukorala and Nasir (2012), Global Production Sharing and South-South Trade, UNCTAD

${ }^{4}$ Network trade refers to trade in both 'parts and components' and 'final assembly.' Trade in final assembly is arrived at by deducting trade in parts and components from the total value of trade.

${ }^{5}$ Kaplinsky and Morris (2001) A Handbook for value chain research, IDRC
} 
Table 1. World Value-Added Exports and Gross Exports

\begin{tabular}{|l|l|l|l|l|l|l|}
\hline & $\begin{array}{l}\text { World Gross } \\
\text { Exports } \\
\text { (million US } \\
\text { dollars) }\end{array}$ & $\begin{array}{l}\text { World Value } \\
\text { Added Exports } \\
\text { (million US } \\
\text { dollars) }\end{array}$ & $\begin{array}{l}\text { World Gross } \\
\text { Exports are } \\
\text { overstated by } \\
(\%)\end{array}$ & $\begin{array}{l}\text { World GDP } \\
\text { (billion US } \\
\text { dollars) }\end{array}$ & $\begin{array}{l}\text { World Gross } \\
\text { Exports as a } \\
\text { proportion } \\
\text { of GDP } \\
(\%)\end{array}$ & $\begin{array}{l}\text { World Value } \\
\text { Added Exports } \\
\text { as a proportion } \\
\text { of Global GDP } \\
(\%)\end{array}$ \\
\hline 1995 & $5,729,887$ & $4,647,776$ & 18.9 & $29,787,337$ & 19 & 16 \\
\hline 2000 & $7,034,013$ & $5,422,147$ & 22.9 & $32,334,431$ & 22 & 17 \\
\hline 2005 & $11,219,686$ & $8,375,755$ & 25.3 & $45,712,154$ & 25 & 18 \\
\hline 2008 & $17,053,224$ & $12,639,788$ & 25.9 & $61,243,561$ & 28 & 21 \\
\hline 2009 & $17,053,224$ & $13,740,267$ & 19.4 & $57,941,672$ & 29 & 24 \\
\hline
\end{tabular}

(Source) OECD-WTO Trade In Value Added (TIVA), May 2013

The extent of the difference between gross exports and value-added exports, varies across countries depending on a country's engagement in network trade. The difference in gross exports and value-added exports is most prominent for Newly Industrialized Countries tier 1 (NICs1) countries like Singapore (50\%), Chinese Taipei (42\%), and Korea (41\%); followed by NICs2 - Malaysia (38\%), Philippines (38\%), and Thailand (35\%); then China (33\%) and Hong Kong (28\%). For most developed countries, foreign value added in gross exports is less than $30 \%$, for example Germany (27\%), the UK (17\%) and the US (11\%). For BRICs countries, especially Brazil and the Russian Federation, this difference is lower as they export a high proportion of commodities. The difference for India and South Africa is $22 \%$ and $16 \%$, respectively. 
Figure 1. Gross Exports and Value Added Exports

(Gap \%, million US dollars, 2009)

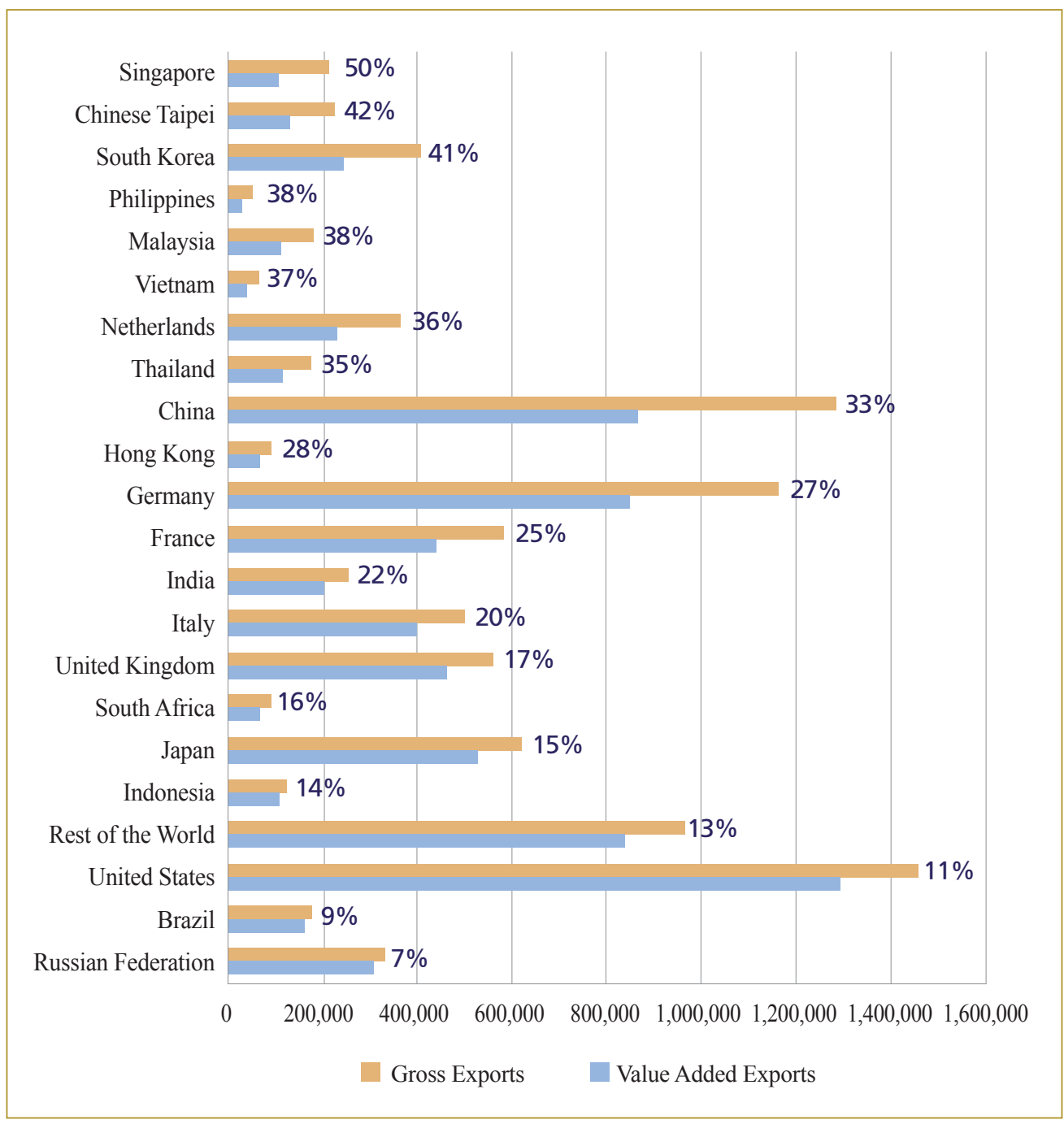

(Source) OECD-WTO Trade In Value Added (TIVA), May 2013

Trends in share of domestic value in gross exports, which is indicative of the value added gains for a country from exports, for the period 1995 2010, reveal interesting insights (Figure 2). Domestic value added in gross exports has declined substantially for many developing countries indicating the rise of foreign value addition in their gross exports. However, domestic value added has increased in this period in Hong Kong, 
Italy, Malaysia, the Russian Federation, and the UK. Such decline in the US has been marginal (3 percentage points) but very high for countries like China (21 percentage points), South Korea (17 percentage points), and India (12 percentage points).

\section{Figure 2. Domestic Value Added in Gross Exports}

(\% changes, the year 2009 over 1995)

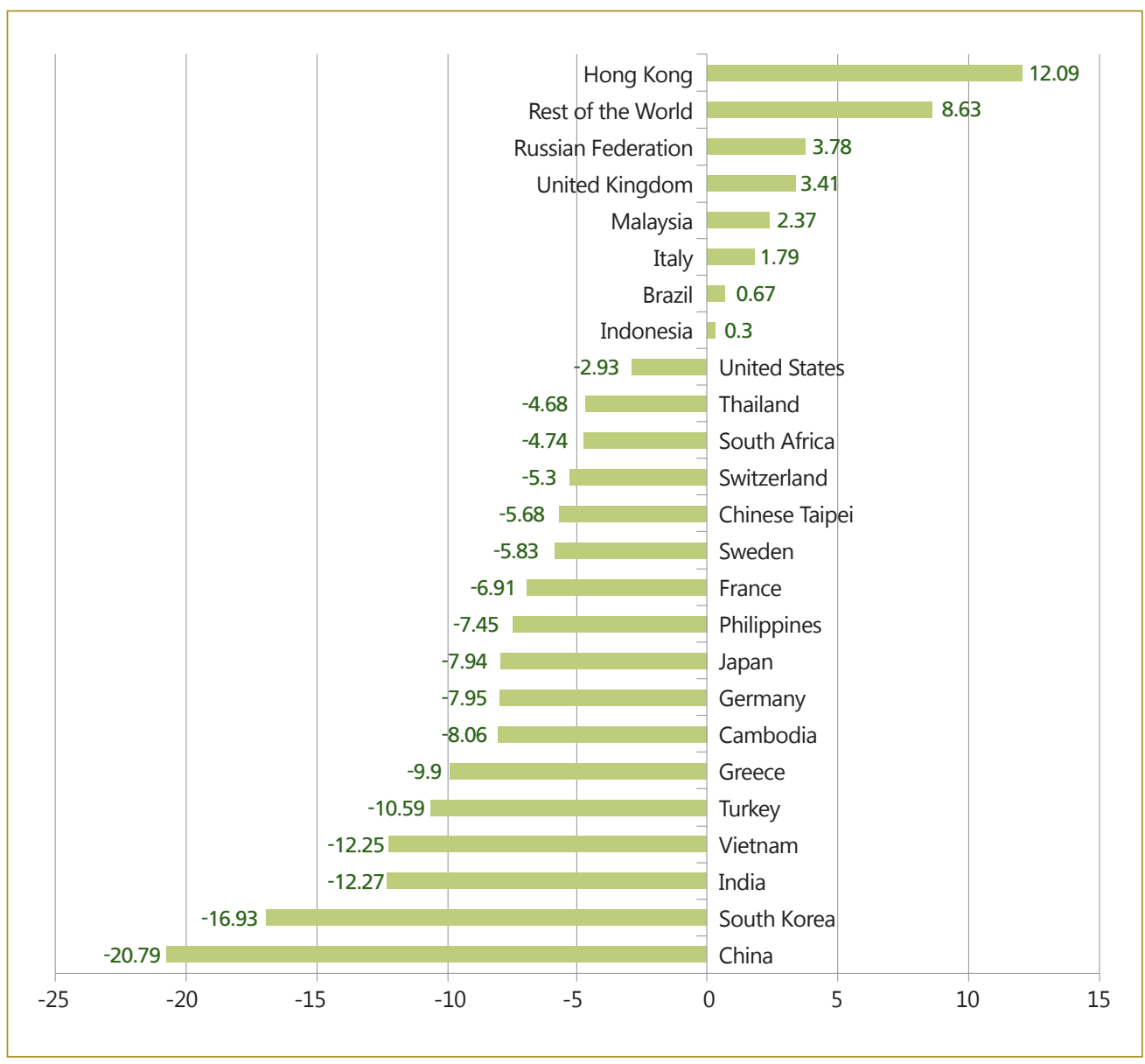

(Source) OECD-WTO Trade In Value Added (TIVA), May 2013

The share of services in global value added exports has increased at a faster rate than that of manufactured products. It rose from $46 \%$ in 2005 to $66 \%$ in 2009 . The highest percentage increase in the share of services in value-added exports is in the case of Germany and the UK (Figure 3). In 2009, the share of services in total value added 
exports was around or greater than $50 \%$ for most of the developed countries in the selected list of countries, while for most of the developing countries it was $40 \%$ or less, except for India where it reached 53\%. In countries like China, Indonesia, Thailand, Malaysia and Vietnam, the share of services in their gross exports is found to be less than $40 \%$.

Figure 3. Share of Services in Value Added Exports

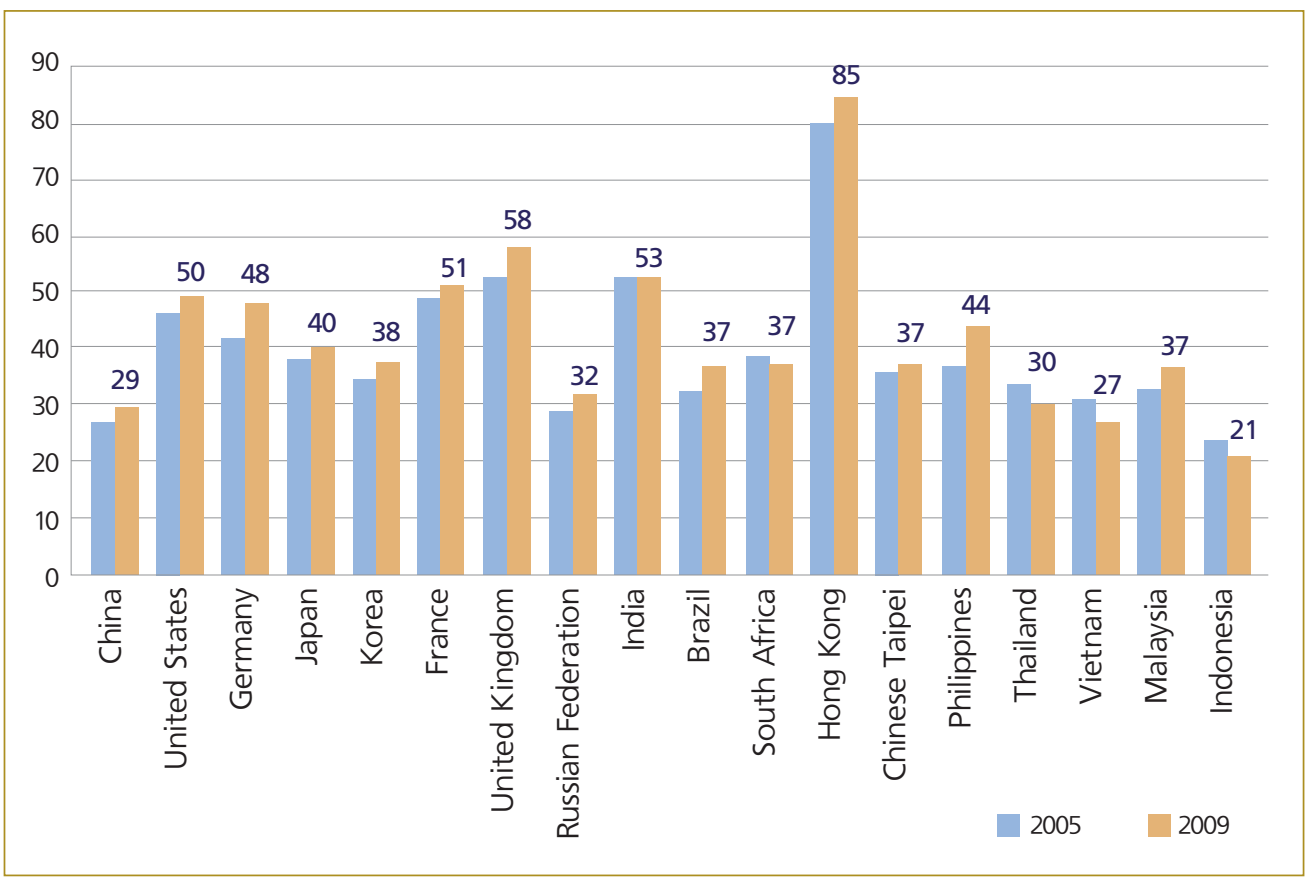

(Source) OECD-WTO Trade In Value Added (TIVA), 2013

Foreign Value Added (FVA) in the gross exports reflects the total value-added created in other countries which adds the value of the exports of a country. This differs from 'import content of exports' in three important ways; (i) This will not be double counted as it includes foreign value-added in all inputs of the products only once and the number of times the inputs across borders will not affect its calculation. It also includes the services component that enters the value addition. (ii) In multi-country value chains, it will contain not just the foreign value added content in bilateral trade but will also contain foreign value added included in exports of the country's bilateral 
trading partner. For example, if China imports intermediate products from Vietnam, FVA content in China's exports will be the sum of value added created in Vietnam, as well as value added created in other countries from which Vietnam imported its inputs for producing its intermediate product. It, therefore, includes all direct imports as well as all indirect imports from countries with which there is no direct trade. This can have important implications for bilateral trade balance. (iii) The re-imported domestic value added will be netted out.

Table 2 reports FVA in gross exports (\%) in 23 selected countries. The highest share of FVA in gross exports is found for NICs1 countries, i.e., Chinese Taipei, Singapore, and South Korea. This is followed by NICs2 countries, mainly the Philippines, Malaysia, and Thailand. Mexico and Vietnam have experienced a steady rise in the share of FVA in gross exports while there has been a steady decline in the case of Hong Kong. 
Table 2. Total Foreign Value Added in Gross Exports

$(\%, 1995 \sim 2008)$

\begin{tabular}{|c|c|c|c|c|}
\hline Countries & 1995 & 2000 & 2005 & 2008 \\
\hline Singapore & 47 & 51 & 52 & 53 \\
\hline Chinese Taipei & 36 & 35 & 42 & 48 \\
\hline South Korea & 24 & 33 & 38 & 43 \\
\hline Philippines & 31 & 46 & 46 & 42 \\
\hline Vietnam & 24 & 30 & 35 & 40 \\
\hline Malaysia & 40 & 43 & 42 & 38 \\
\hline Thailand & 30 & 35 & 38 & 38 \\
\hline China & 12 & 19 & 36 & 33 \\
\hline Mexico & 27 & 32 & 31 & 31 \\
\hline Hong Kong & 41 & 33 & 28 & 29 \\
\hline Germany & 19 & 24 & 26 & 28 \\
\hline France & 18 & 24 & 25 & 27 \\
\hline India & 10 & 13 & 20 & 24 \\
\hline Italy & 22 & 25 & 27 & 23 \\
\hline South Africa & 12 & 16 & 17 & 21 \\
\hline Japan & 7 & 10 & 14 & 19 \\
\hline United Kingdom & 21 & 18 & 20 & 19 \\
\hline Indonesia & 15 & 19 & 18 & 17 \\
\hline Norway & 19 & 15 & 14 & 15 \\
\hline United States & 8 & 9 & 12 & 15 \\
\hline Australia & 12 & 14 & 13 & 14 \\
\hline Brazil & 10 & 11 & 13 & 11 \\
\hline Russian Federation & 11 & 13 & 8 & 7 \\
\hline
\end{tabular}

(Source) OECD Statistics and OECD-WTO TIVA, May 2013

Shares of FVA in gross exports for most developed countries have remained less than $30 \%$, while those of Australia, Japan, the US, and the UK has remained less than $20 \%$. This brings us to the question of whether FVA in gross exports is an appropriate 
indicator to measure the extent of a country's participation in GVCs. We examine this issue in detail in the next section.

\section{Gains from Global Value Chains}

\section{A. Measuring Participation}

GVCs penetrate across industries and countries and are increasingly using services. Advancements in Information and Communication Technology (ICT) have added new dimensions to trade, as many services which were earlier included in the production process can now be off-shored. One of the challenges facing developing countries in this scenario is to estimate their extent of participation in GVCs and their net valueadded gains from this participation. The conceptual issue of what part of trade can be categorized as trade under GVCs, arises from this estimation issue. It is more complicated to measure at the country level.

Literature on GVCs uses the measure of "vertical specialization" ${ }^{6}$ to gauge a country's competitiveness in GVCs, estimating separately for intermediate and finished products (Hummels et al. 1998, 2001, Chen et al. 2005) to gauge the relative competitive position of a country in value chains.

Distribution of gains across countries under GVCs is an important issue which may highlight the importance of GVCs for developing countries. Many studies have pointed out that gains are unevenly distributed across value chains (Gereffi 1994, Kaplinsky 1998, Schmitz 2006, Fitter and Kaplinsky 2001, Kaplinsky and Fitter 2004, Kaplinsky 2005, Milberg 2009, Baldwin 2012). The balance of power often favors nodes with high technology. This would imply that firms which control technology through patents or licenses are in extremely powerful positions and are likely to extract maximum rents in GVCs. But technology may not be sufficient to maximize rents in value chains, as higher rents may also accrue to nodes with better organizational skills and marketing capabilities with the use of brand names. To extract maximum rents, governance becomes an important element in the value chain.

\footnotetext{
${ }^{6}$ Vertical specialization occurs when a country uses imported intermediate parts to produce goods it later exports. This definition captures the idea that countries link sequentially to produce final goods.
} 
Gereffi and Korzeniewicz's (1990) elaboration of the commodity chain concept illustrates that in low-wage labor-intensive production, the principal profits are not realized in manufacturing itself, but rather in the corporate coordination and control of the entire global assembly line, especially design, marketing, and retailing-activities that are typically controlled by transnational firms based in core countries. In this complicated chain of events and functions, peripheral countries often remain primarily export platforms for simple low-technology, labor-intensive goods made by low-wage unskilled workers. This adds to the challenge of overcoming technological dependence for non-core countries. This explains why Indonesian factories that subcontract to produce huge quantities of the latest models of Nike sports shoes retain only a tiny proportion of the global corporation profits on the shoes (Ballenger 1992). Case studies for China show that for the Apple iPod, only 4 US dollars out of the total value of 150 US dollars can be attributed to producers located in China while most of the value accrues to Japan, South Korea, and US (Dedrick, Kraemer, and Linden, 2009). Although case studies point out the uneven distribution of gains in GVCs, very few studies estimate the extent of countries' participation in GVCs and the distribution of total value-added gains under GVCs.

For a particular country, especially a developing country, linking into GVCs could either be through forward linkages where the country provides inputs into exports of other countries or through backward linkages where the country imports intermediate products to be used in its exports. The share of a country in total value-added created by forward and backward linkages in GVCs can provide a measure of the extent of a country's participation and its relative gains in GVCs. Using the OECD-WTO TIVA dataset (May 2013), participation in GVCs is estimated for each of 58 countries that include 34 OECD countries, 5 BRICs (Brazil, the Russian Federation, India, China, and South Africa), NICs (China, China Taipei, Hong Kong, Korea, Malaysia, Philippines, Singapore, and Thailand), and the category, rest of the world, which comprises all developing and under-developed countries other than BRICs and NICs.

Figure 4 shows the distribution of global value added created by GVCs in 2009. The share of OECD countries in total value-added created by GVCs is found to be $67 \%$, the share of NICs1 (Chinese Taipei, Korea, and Singapore) is around $8 \%$, and the NICs 2 (China, Hong Kong, Malaysia, Philippines, and Thailand) account for around 3\%. BRICs countries comprise $14 \%$, of which share of China accounts for $9 \%$. However, the share of rest of the world, which includes all LDCs and other developing countries (excluding NICs and BRICs), is $8 \%$. Among the OECD countries, the share of the 
top six countries - the US (9\%), Germany (9\%), the UK (4\%), Japan (4\%), South Korea (5\%), and France (4\%) is around 35\%. Adding China to this list would result in covering almost $45 \%$ of global value added created by GVCs.

\section{Figure 4. Share in Global Value Added Exports in Global Value Chains}

(2009)

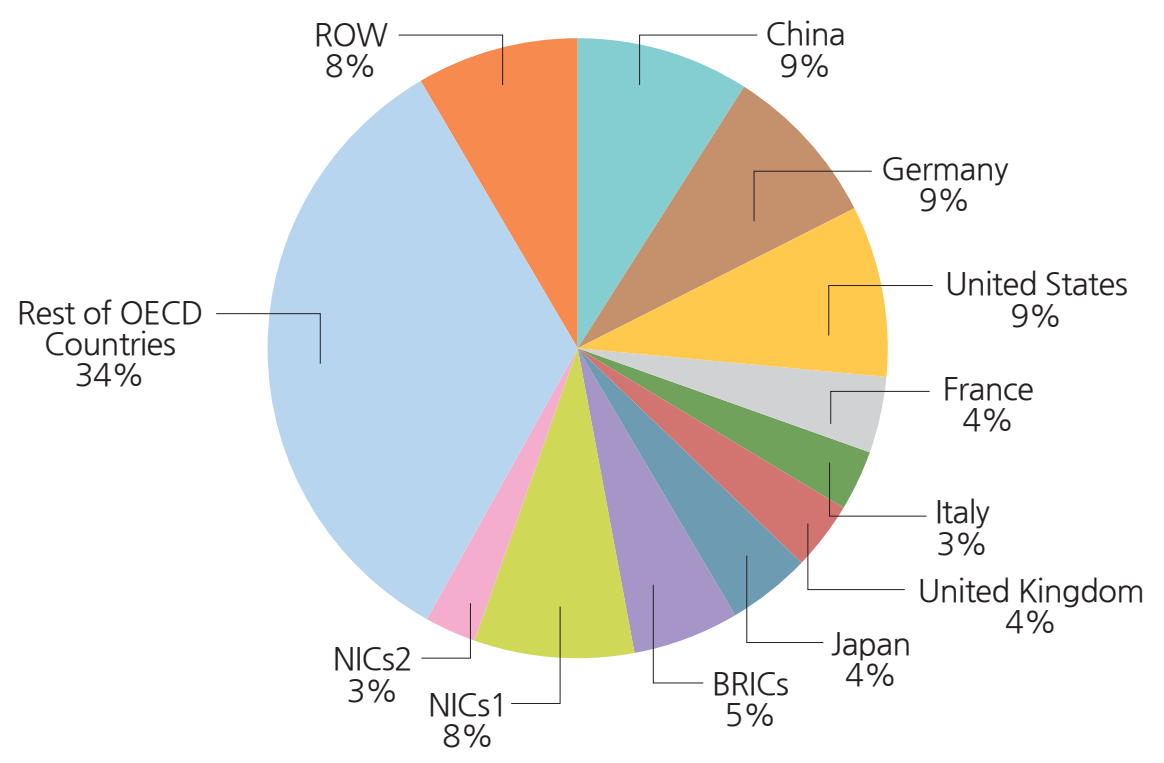

(Note) NICs1: Chinese Taipei, Korea, and Singapore

NICs2: China, Hong Kong, Malaysia, Philippines, and Thailand

(Source) OECD Statistics and OECD-WTO TIVA, 2013

The highest levels of participation in GVCs, in terms of share in total value-added created in GVCs were found in China (9\%) and the US (9\%). Excluding the share of China, the BRICs' share is only around 5\%. All other developing countries together share less than $10 \%$ of global value added created by GVC participation. Further, if the share of China is estimated in terms of the total participation of developing countries in GVCs, it is as high as $30 \%$. The share of China in the backward linkages of OECD countries with developing countries is as high as 33\% while the share of China in forward linkages of OECD countries is 34\%. FVA from OECD countries in China's gross exports amounts to $78 \%$ of its total FVA in gross exports while it contributes around $65 \%$ of its value added to exports that enter the gross exports of OECD 
countries. This would imply that the gross exports of China create much more valueadded in developed countries as compared to developing countries. Since most of the GVCs emerge from OECD countries, China can be called the epicenter of GVCs in the developing world for developed countries.

One of the reasons for the high share of OECD countries in value-added created in GVCs is the fact that most GVCs are initiated and end in these countries, with the lead firms mostly based in these countries. These firms provide pre-manufacturing and postmanufacturing services like R\&D, design, branding, and distribution services, which capture the maximum value-added generated in GVCs. Most of the developing and least developed countries are either stuck at the bottom of GVCs, providing raw materials to the chain or add little value to their manufactured exports, which capture lower values. Even in low-tech industries like textiles, textile products, and leather and footwear, where countries like China and India have comparative advantage in manufacturing and most of the raw materials are supplied by least developed countries in Africa and Asia, the lead firms in the existing GVCs are based in developed countries like Italy and the United States. The next sections discuss these aspects in more detail.

\section{B. Measuring Distribution of Gains}

Higher participation in GVCs may not ensure higher gains. A break-up of forward linkages and backward linkages in GVCs can provide useful insight into the gains from its participation in GVCs. If gains are measured in terms of 'net value-added' by participation in GVCs, then increasing the proportion of forward linkages compared to backward linkages increases such gains. In terms of participation in GVCs, China, the US, and Germany have the highest participation rate (9\%), followed by Japan (4.5\%), France (4\%), South Korea (4\%), the UK (4\%), and Italy (3\%).

Participation in the forward linkages of GVCs, which is the extent of domestic value-added that enter exports of other countries, is found to be highest for the US $(12.6 \%)$ followed by Germany ( $8 \%$ ); while the share of FVA in exports, i.e., backward linkage is found to be highest in China (12.6\%) followed by Germany $(9.3 \%)$. The ratio of the two shares for a country indicates that country's net gains in terms of value-added by participating in GVCs. High participation in GVCs (greater than 3\%) and a ratio of forward linkage to backward linkage higher than 1 is found for Italy, Japan, the US, and the UK. If a country is an exporter of commodities or primary inputs, its forward 
linkages will be much higher than its backward linkages such as Brazil, Indonesia, Russia, and South Africa. These countries will correspondingly show low participation in GVCs.

China, Germany, and the US have a high total participation in GVCs. The US has much stronger forward linkages than its backward linkages (a ratio of 2.53). The ratio is 0.5 for China, indicating that China's domestic value-added that enters other countries' exports is much lower than what it imports from other countries. This substantiates the results obtained by the case studies on China. 
Table 3. Participation in GVCs by Forward and Backward Linkages

\begin{tabular}{|c|c|c|c|c|}
\hline Countries & $\begin{array}{c}\text { Participation } \\
\text { in GVC in terms of share } \\
\text { in total value added } \\
\text { created by GVCs } \\
(\%)\end{array}$ & $\begin{array}{c}\text { Share in } \\
\text { Forward } \\
\text { Linkages } \\
(\%)\end{array}$ & $\begin{array}{c}\text { Share in } \\
\text { Backward } \\
\text { Linkages } \\
(\%)\end{array}$ & $\begin{array}{c}\text { Ratio of } \\
\text { Forward to } \\
\text { Backward } \\
\text { Linkages }\end{array}$ \\
\hline China & 8.9 & 5.2 & 12.6 & 0.41 \\
\hline United States & 8.8 & 12.6 & 5.0 & 2.53 \\
\hline Germany & 8.7 & 8.0 & 9.3 & 0.86 \\
\hline Japan & 4.5 & 6.1 & 2.8 & 2.23 \\
\hline France & 4.0 & 3.7 & 4.4 & 0.85 \\
\hline South Korea & 3.9 & 3.0 & 4.9 & 0.60 \\
\hline UK & 3.6 & 4.2 & 2.9 & 1.45 \\
\hline Italy & 3.1 & 3.3 & 3.0 & 1.08 \\
\hline Chinese Taipei & 2.4 & 2.0 & 2.8 & 0.71 \\
\hline Russia & 2.3 & 4.5 & 0.7 & 6.51 \\
\hline Vietnam & 2.1 & 0.3 & 0.7 & 0.40 \\
\hline Mexico & 1.5 & 0.8 & 2.1 & 0.38 \\
\hline Australia & 1.3 & 1.8 & 0.7 & 2.50 \\
\hline Norway & 1.2 & 1.8 & 0.7 & 2.54 \\
\hline Hong Kong & 1.2 & 0.8 & 0.8 & 0.95 \\
\hline South Africa & 1.1 & 0.4 & 0.4 & 1.05 \\
\hline Brazil & 1.0 & 1.4 & 0.5 & 3.01 \\
\hline Singapore & 0.8 & 1.3 & 3.2 & 0.42 \\
\hline Thailand & 0.8 & 1.0 & 1.8 & 0.53 \\
\hline Malaysia & 0.8 & 1.5 & 2.1 & 0.73 \\
\hline Indonesia & 0.6 & 1.1 & 0.5 & 2.03 \\
\hline Philippines & 0.4 & 0.4 & 0.6 & 0.74 \\
\hline India & 1.1 & 1.6 & 1.7 & 0.93 \\
\hline NICs1 & 10.5 & 11.2 & 11.7 & 0.96 \\
\hline NICs2 & 2.6 & 4.0 & 5.0 & 0.80 \\
\hline BRICs & 14.4 & 13.1 & 15.9 & 0.82 \\
\hline
\end{tabular}

(Notes) Forward linkage: domestic value added exports which enter other countries' exports as a proportion of global value-added exports in GVCs (\%)

Backward linkage: foreign value added content in the value added exports of a country as a proportion of global value added exports in GVCs (\%)

(Source) OECD Statistics and OECD-WTO TIVA, May 2013 


\section{Structure of Global Exports}

The manner in which participation in GVCs is defined can give completely different results depending on which part of GVCs is focused on. Earlier literature mainly focused on the import content of exports. Figure 5 shows the structure of the gross exports of the world. Domestic value added by manufacturing contributes the largest portion of gross exports, globally contributing $43 \%$ of total gross exports while domestic value added services contribute 33\%. FVA which constitute global value chains comprise $24 \%$, of which $10 \%$ is contributed by services sectors. The share of FVA in manufacturing, where all developing countries can hope to gain constitutes only $14 \%$ of total gross exports. This $14 \%$ of value added is divided among developed as well as developing countries.

\section{Figure 5. Structure of Global Gross Exports}

(2009)

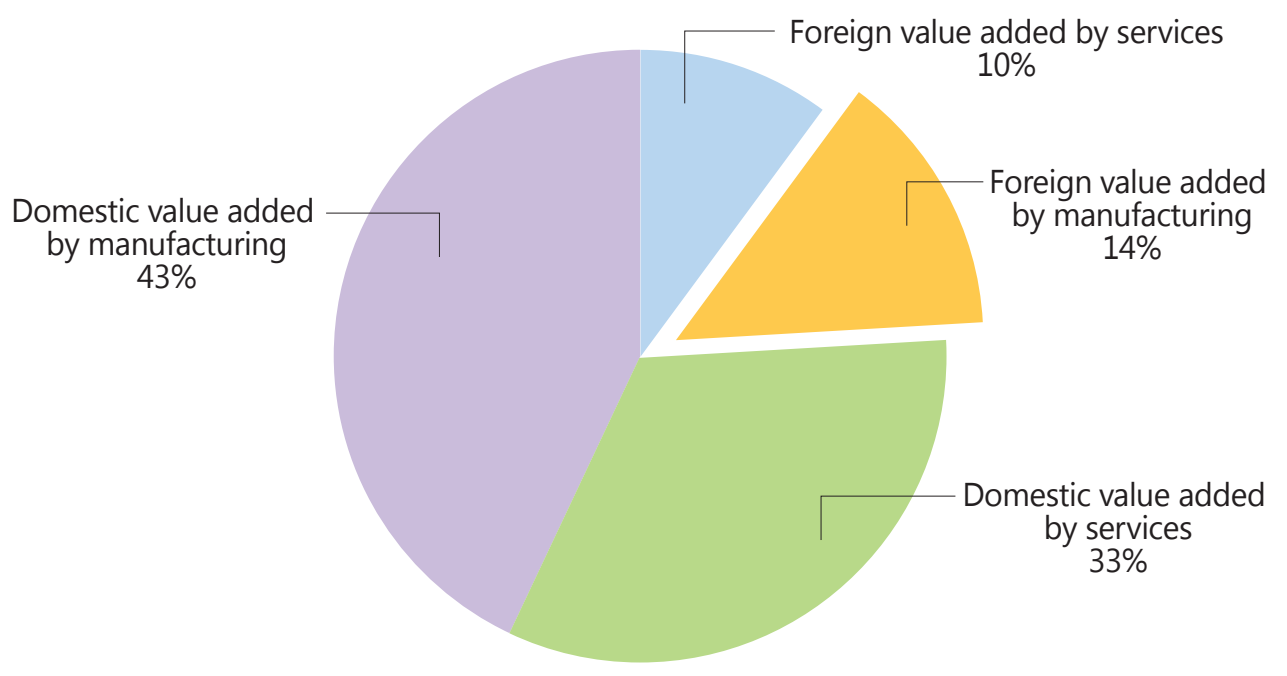

(Source) OECD Statistics and OECD-WTO TIVA, May 2013

In value-added terms, studies have focused on FVA in gross exports. However, for cross-country comparisons these indicators can clearly give a misleading picture. Figure 6 exhibits the structure of the gross exports of some countries. In terms of FVA in gross exports, the US appears to be one of the least integrated countries in GVCs as the 
proportion of FVA in its gross exports was only around 11\% while a country like India, whose share in global value-added in GVCs is around 22\% may appear to be more integrated than the Japan or the US.

The forward linkages may reveal direct gains from GVC participation in terms of domestic value addition. For Japan, the US, and the UK, the share of forward linkage of GVCs in their gross exports is between $25 \% \sim 33 \%$. China, however, appears to be integrated at a much higher level in terms of backward linkages. In fact, China's domestic value-added exports used in other countries' exports in GVCs are one of the lowest among the selected countries. For countries that export commodities and other primary inputs, only forward linkages may not correctly show their extent of GVC participation as most of their domestic value-added exports will enter the exports of other countries, e.g., in case of Russia, this is $46 \%$ and around 29\% for Brazil and Indonesia.

\section{Figure 6. Structure of Gross Exports}

(2009)

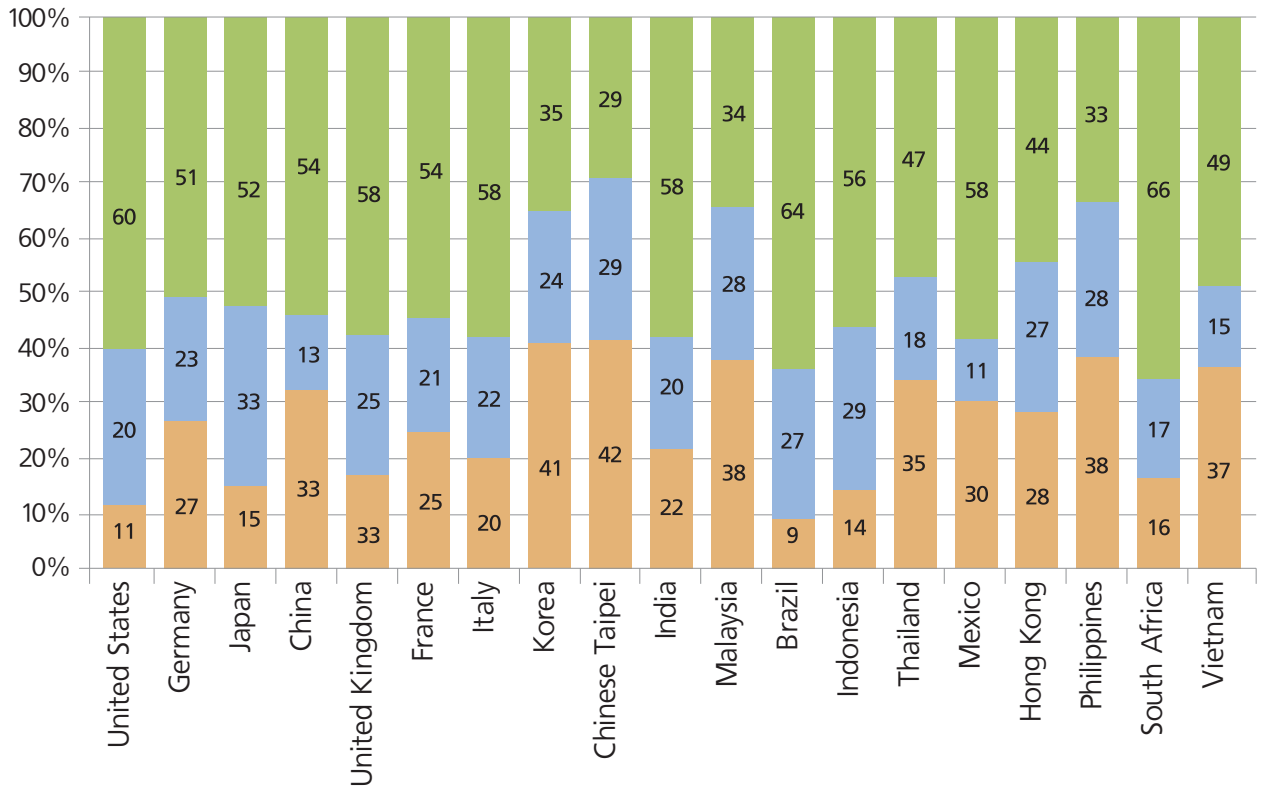

Foreign value added in gross exports

Domestic Value Added Exports used in other countries' exports(Forward linkages)

Domestic Value Added Exports using other countries' domestic demand (Backward linkages)

(Source) OECD Statistics and OECD-WTO TIVA, May 2013 
Getting linked to GVCs in forward linkages may be used as a strategy for boosting growth in industries, may not be the right strategy for all industries. However, backward linkages may be useful for improving the cost competitiveness of gross exports. For example, South Korea, which has high backward linkage (41\%) and relatively high forward linkage $(24 \%)$ has the lowest value for the domestic value-added exports of final products.

\section{The Role of Services in Global Value Chains}

The share of services in global trade is rising rapidly and so is the role of services in GVCs. Improvements in technology, standardization, infrastructure growth, rapid advances in Information and Communication Technology (ICT), and decreasing data transmission costs have all contributed to the tradability of services. Building on Porter (1985) value systems, studies like Gereffi (1999), Mitsuhashi (2005), and Mudambi (2007) have emphasized that functional upgrading in GVCs provides the rents. The much discussed 'smiley curve' shows that services capture more value at both ends i.e., pre manufacturing services and post manufacturing services as compared to manufacturing activities which are at the bottom, capturing less value as compared to services. Gereffi and Korzeniewicz (1990) argues that the principal profits are not realized in manufacturing itself, but rather in the corporate coordination and control of the entire global assembly line.

Given the important role played by services in upgrading in GVCs, the contribution of services in global value-added is estimated for each country using input-output tables. It is found that services contribute $45 \%$ to global value-added exports. However, this differs significantly across countries. Figure 7 breaks down the gross exports into FVA by manufactured products, FVA by services, domestic value-added by manufactured products, and domestic value added by services. 


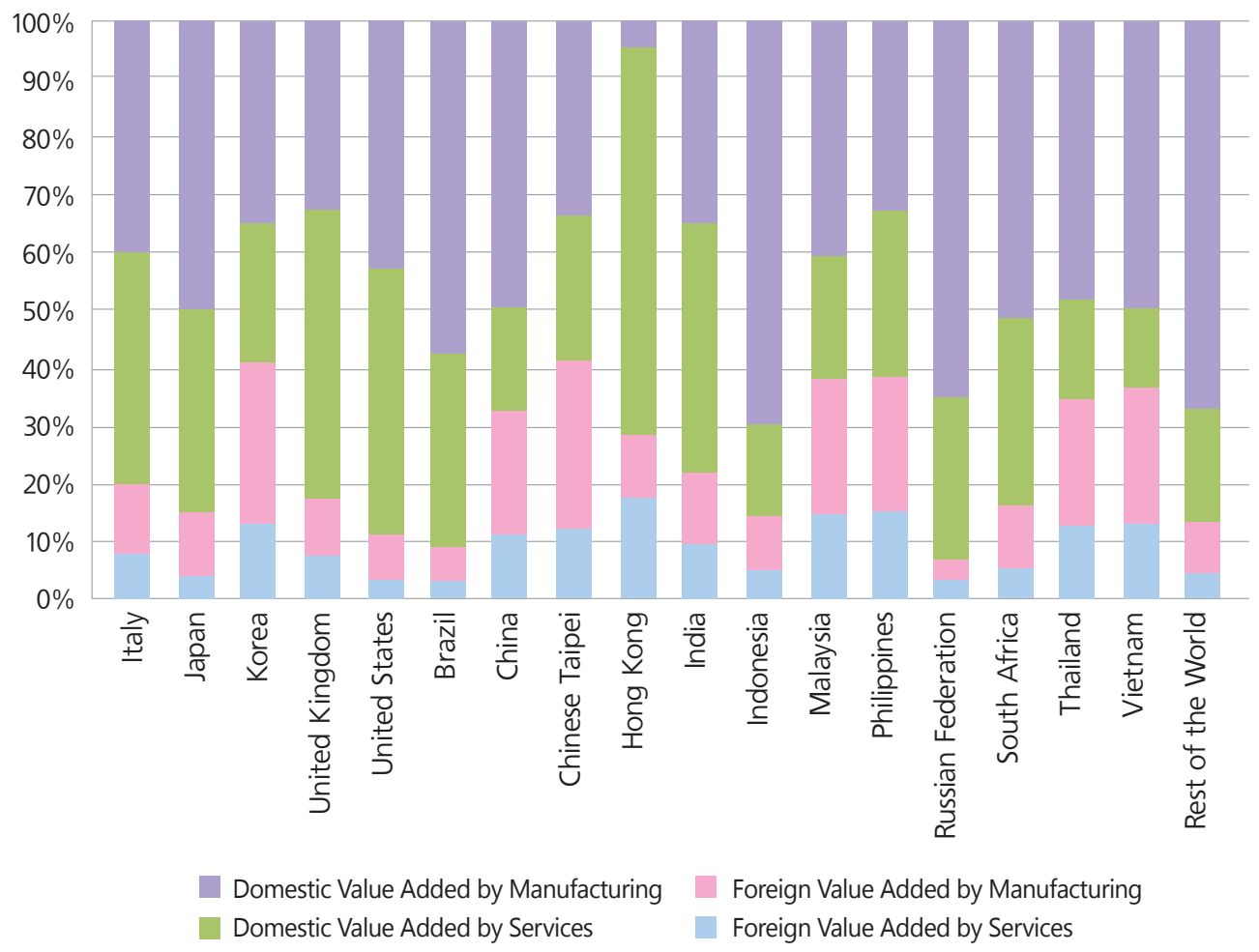

(Source) OECD Statistics and OECD-WTO TIVA, May 2013

For OECD countries, the contribution of services in value-added exports is almost $50 \%$. Out of this, $39 \%$ is sourced domestically and $11 \%$ is sourced from other countries. For BRICs countries, value addition from services in their total value-added exports is $33 \%$, of which $8 \%$ is sourced from other countries. In China, most of the value-added by exports is created in the manufacturing sector, while services contributed $29 \%$ of total value added exports in 2009 , with $40 \%$ imported from other countries. While in India, most of the value-added exports are from the services sector which contributes $53 \%$ to value-added exports. Foreign value added from manufactured products and services is almost equal in the case of India. In other developing countries like Indonesia, the contribution of services is less than $20 \%$ with only $5 \%$ of value-added contributed to its exports from other countries.

What is striking in the above analysis is the fact that services play a much more dominant role in the value-added contribution to the exports of developed countries. 
Overall, in the OECD countries, the contribution of domestic value-added to total exports from services is greater than the contribution of domestic value-added to exports by manufactured products, with a higher share of services seen in the cases of France, the US, and the UK. Domestic value-added in exports by manufactured products play a dominant role in developing countries. The backward linkages in services are also not strong for developing countries. Developing countries may stand little chance of maximizing gains through functional up-grading in value chains.

\section{Global Value Chains Bypass Low-Tech Industries}

Low-tech industries which are the major job creators in most developing and least developed countries, have not experienced much production fragmentation brought by GVCs as seen in high-tech and medium-tech industries like electrical and optical equipment, machinery and equipment, transport equipment, and chemicals. Figure 8 shows the share of foreign value added entering the exports of low-tech and high-tech industries in different countries. While in developed countries, GVCs are expected to concentrate in high-tech industries, in developing countries like BRICs, as well as other developing countries (NICs1 and NICs2), the share of low tech industries is very small in total FVA entering gross exports. In China, total gross exports included $28 \%$ of foreign value-added of which only $15 \%$ entered low-tech industries. 


\section{Figure 8. Foreign Value Added in the Gross Exports} of High-Tech and Low-Tech Industries

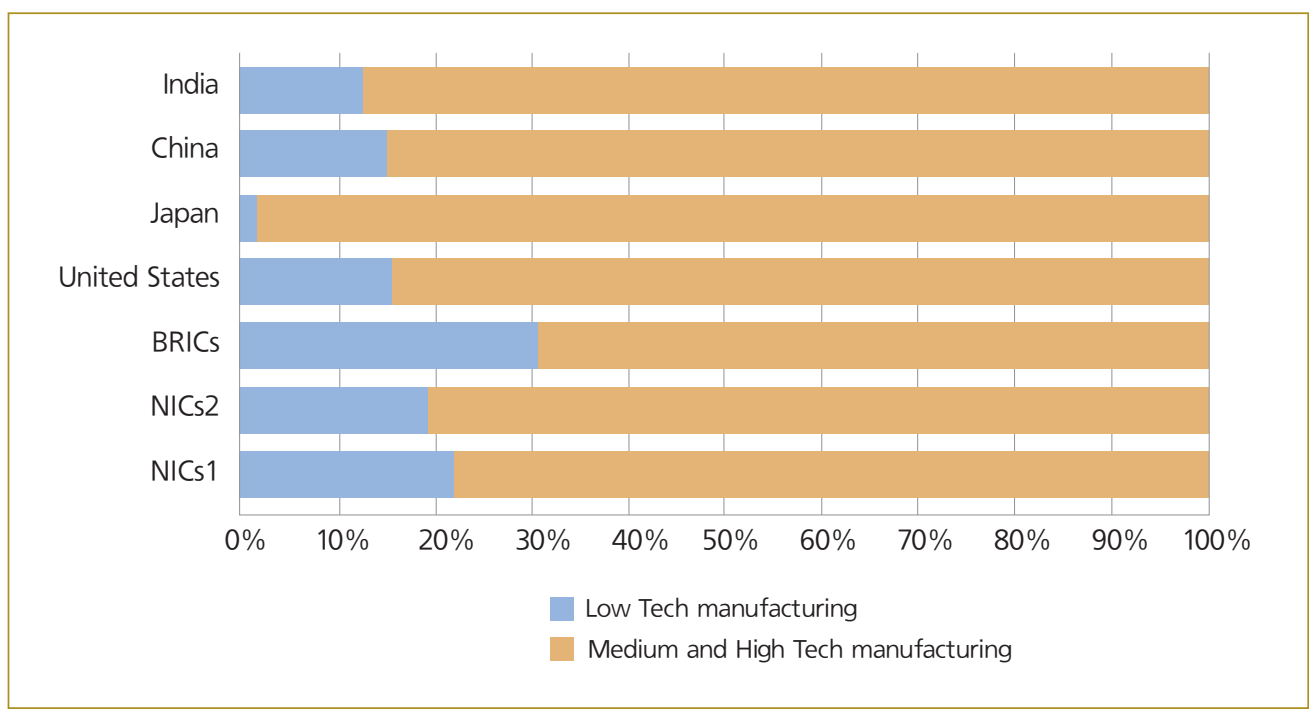

(Note) High tech industries comprise Electrical and optical equipment; Machinery and equipment, nec; Transport equipment; and Chemicals and non-metallic mineral products

Low-tech industries comprise Textiles, textile products, leather and footwear; Wood, paper, paper products, printing and publishing; Food products, beverages and tobacco; Agriculture, hunting, forestry and fishing; Mining and quarrying; and Manufacturing nec; Recycling

(Source) OECD Statistics and OECD-WTO TIVA, 2013

Figure 9 shows the comparison of backward linkages, i.e., FVA in the gross exports of China, India, and the US. India has higher share of FVA in gross exports in services sectors, while China has a higher share in manufacturing sectors. The US has a lower share of FVA in its gross exports and higher domestic value added share as compared to China and India in almost all sectors.

Even in the case of high-tech industries, the participation of developing countries in GVCs may not ensure net gains in terms of value-added created by trade (Table 4). The net value-added in exports in GVCs is positive in the case of developed countries. In machinery and equipment, the domestic value added of US imports is higher than the foreign value added in exports of the US. Japan and the UK also experience a net gain in their participation in GVCs. In the machinery and equipment industries, India, the Philippines, Thailand, and Vietnam the ratio is greater than 1. Japan, the US, and the UK experience net gains by their participation in GVCs in chemicals and non-metallic 
mineral products. In low-tech industries such as textiles, textile products, leather, and footwear, Italy's net gains from participation in GVCs are higher than that of China's. India has a greater than 1 ratio in all the three sectors. 
Figure 9. Share of Foreign Value Added in Gross Exports in China, India, and the United States

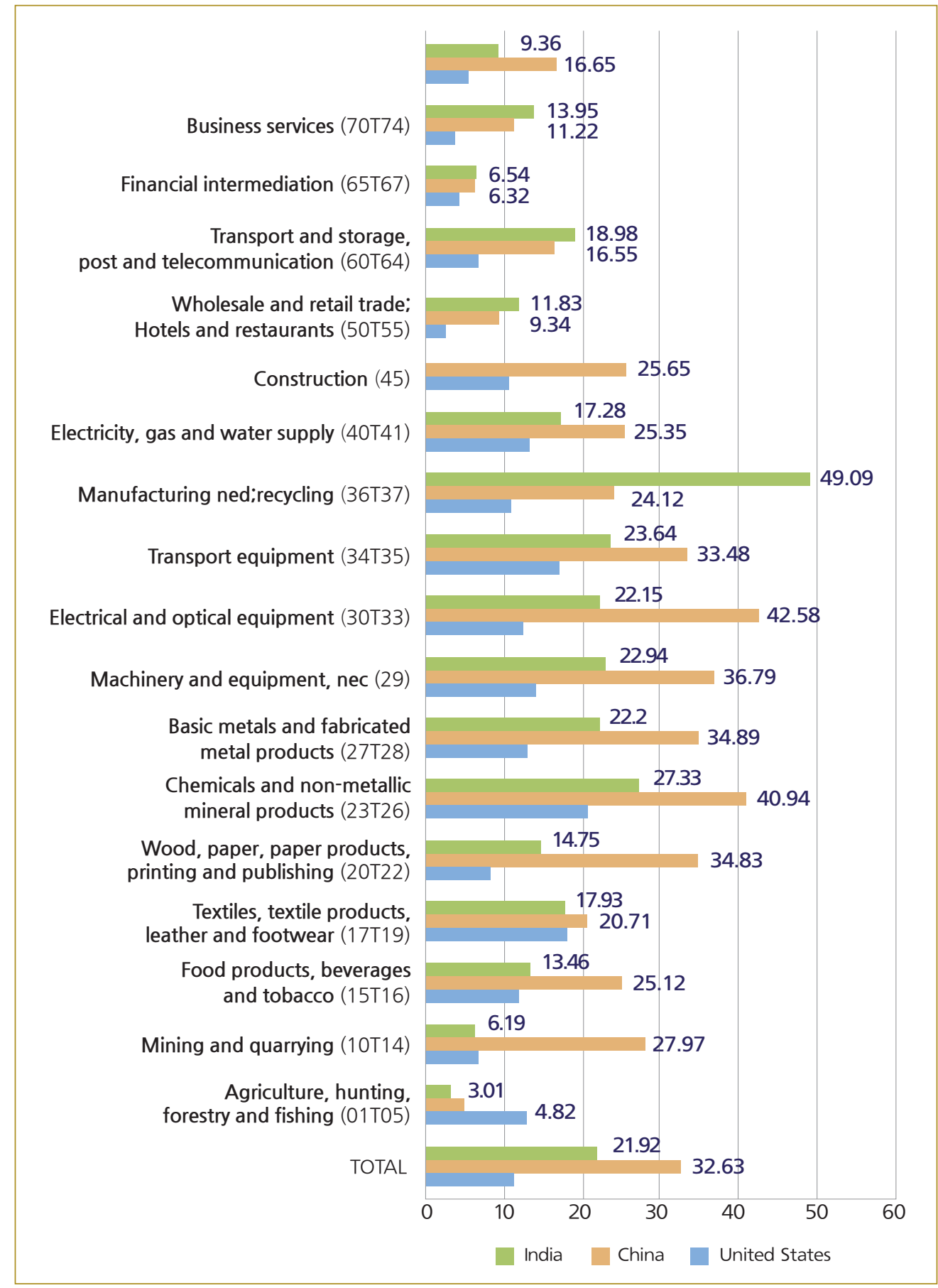

(Note) Based on industrial classification of TIVA(OECD-WTO Trade In Value Added dataset) 
Table 4. Net Value Added in Exports in the GVCs

: Ratio of Forward to Backward Linkages

\begin{tabular}{|c|c|c|c|}
\hline Countries & $\begin{array}{c}\text { Machinery and } \\
\text { Equipment }\end{array}$ & $\begin{array}{c}\text { Chemicals and } \\
\text { Non-metallic Mineral } \\
\text { Products }\end{array}$ & $\begin{array}{c}\text { Textiles and } \\
\text { Clothing }\end{array}$ \\
\hline United States & $\mathbf{2 . 2}$ & $\mathbf{1 . 5}$ & $\mathbf{7 . 6}$ \\
\hline Germany & 0.6 & 0.6 & 3.2 \\
\hline Japan & $\mathbf{2 . 5}$ & $\mathbf{1 . 5}$ & 0.3 \\
\hline China & 0.4 & 0.3 & $\mathbf{2 . 1}$ \\
\hline United Kingdom & $\mathbf{1 . 5}$ & $\mathbf{1 . 3}$ & $\mathbf{1 . 1}$ \\
\hline France & 1.0 & 0.6 & $\mathbf{1 . 6}$ \\
\hline Italy & 0.9 & 0.6 & $\mathbf{1 . 6}$ \\
\hline South Korea & 0.9 & 0.2 & $\mathbf{1 . 4}$ \\
\hline Chinese Taipei & 1.1 & 0.2 & $\mathbf{1 . 3}$ \\
\hline India & 2.3 & 1.6 & 0.9 \\
\hline Malaysia & 0.2 & 0.6 & 0.5 \\
\hline Indonesia & 0.9 & 2.7 & 0.5 \\
\hline Thailand & 1.4 & 0.6 & 0.4 \\
\hline Mexico & 0.9 & 1.5 & \\
\hline Philippines & 4.4 & 5.2 & 0.1 \\
\hline Vietnam & 1.1 & & 0.2 \\
\hline
\end{tabular}

(Source) OECD Statistics and OECD-WTO TIVA, May 2013

\section{Structure of Value-Added Exports of China in Electrical and Optical Equipment:}

China is one of the biggest exporters in electrical and optical equipment. In 2009, its exports were accounted for 466 billion US dollars out of 1.7 trillion US dollars of total world exports. The domestic value-added in Chinese exports was only $57 \%$ of its total exports. The share of different countries in the gross Chinese exports is depicted in Figure 10. The value added is created in Japan (6\%) by Chinese exports, followed by Chinese Taipei, South Korea, and the US (5\%). 


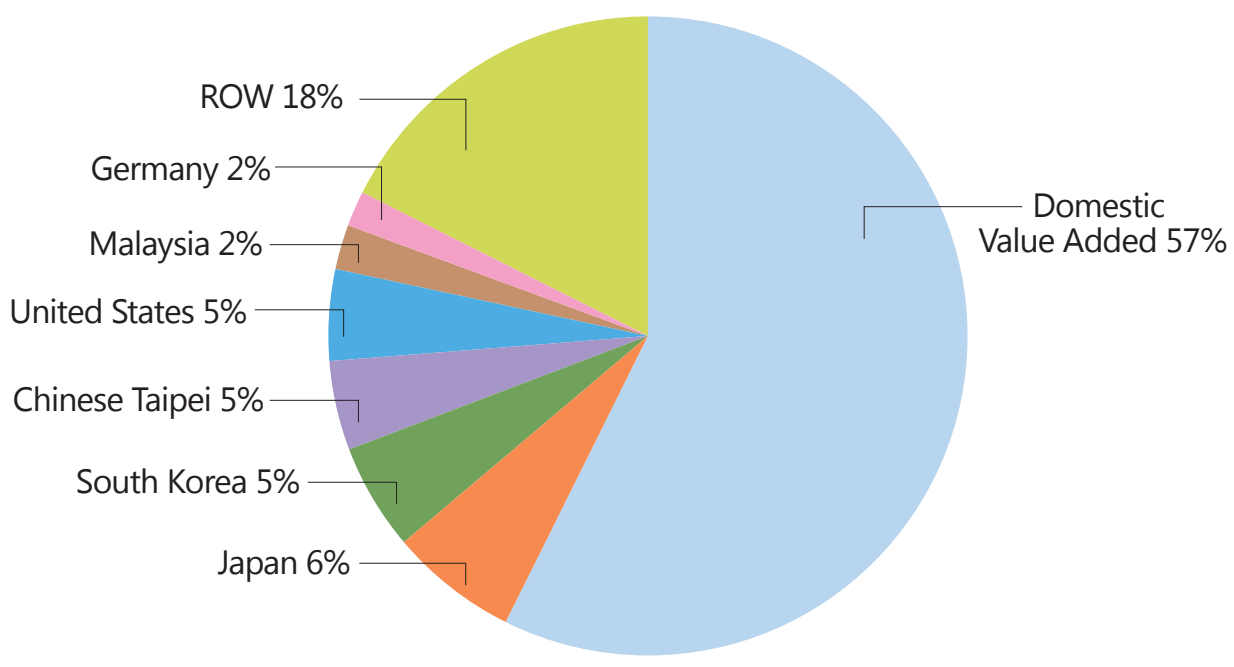

(Source) OECD Statistics and OECD-WTO TIVA, May 2013

\section{Structure of Value Added Exports of China} in Textiles, Textile Products, Leather, and Footwear:

In textiles, textile products, leather, and footwear, one of the low-tech industries which has often been identified as an industry with prominent GVCs, the breakdown of gross Chinese exports reveals interesting insights. China's share in global exports of this sector is $40 \%$ while its share in total developing countries exports is $64 \%$. In 2009 , China's gross exports comprised 218 billion US dollors, of which foreign value added was 32 billion US dollors. China's backward linkages are found to be stronger with developed countries as compared to developing countries, with the relative shares of Japan, South Korea, and the US being around 10\% each. However, China's contribution of value-added to developing countries exports is found to be relatively higher as compared to developed countries. 
Table 5. Share of Developed and Developing Countries in China's Backward and Forward Linkages in Global Value Chain

(in Textiles, Textile Products, Leather, and Footwear)

\begin{tabular}{|l|c|c|c|c|c|}
\hline & $\begin{array}{c}\text { Share of } \\
\text { Developing } \\
\text { countries (\%) }\end{array}$ & $\begin{array}{c}\text { Share of } \\
\text { Developed } \\
\text { countries (\%) }\end{array}$ & $\begin{array}{c}\text { Share of } \\
\text { United States } \\
(\%)\end{array}$ & $\begin{array}{c}\text { Share } \\
\text { of Japan } \\
(\%)\end{array}$ & $\begin{array}{c}\text { Share of } \\
\text { South Korea } \\
(\%)\end{array}$ \\
\hline $\begin{array}{l}\text { Backward linkage } \\
\text { (Foreign value added } \\
\text { in gross Exports) }\end{array}$ & $45 \%$ & $55 \%$ & $10 \%$ & $11 \%$ & $9 \%$ \\
\hline $\begin{array}{l}\text { Forward linkages } \\
\text { (Domestic value added } \\
\text { in other countries? } \\
\text { exports) }\end{array}$ & $65 \%$ & $35 \%$ & $3 \%$ & $2 \%$ & $8 \%$ \\
\hline
\end{tabular}

(Source) OECD Statistics and OECD-WTO TIVA, 2013

What emerges from the sectoral analyses of value-added created under GVCs is that high-tech industries have much higher fragmentation of production processes and far more GVCs as compared to low-tech industries. Domestic value-added in hightech industries in developing countries may not be very high. Even in industries where developing countries like China have the highest share of global exports, e.g., electrical and optical equipment, a large part of value-added is sourced from developed countries from where most of the transnational corporations operate. In low-tech industries, like textiles and leather, although the comparative advantage of developing countries is higher by definition as they involve large-scale low-wage employment, the backward linkages with developed countries in terms of foreign value-added used in exports is high. The gains of exports are therefore being fragmented along the global value chains with the balance of power favoring developed countries.

\section{Conclusion}

Linking into GVCs is increasingly being considered as a new development challenge in developing countries. GVCs are expected to bring gains to the linked 
countries via improved competitiveness, better access to global markets, and expansion of production and jobs. However, whether countries realize these gains or not is still not clear mainly because the tools to measure a country's extent of participation in GVCs and distribution of incomes generated from GVCs across countries are limited. The rising share of intermediate products in total trade has challenged the use of traditional tools like export shares in assessing countries' competitiveness. Higher export shares may not necessarily imply higher competitiveness if exports contain a large share of imported intermediate products. In a similar fashion, higher exports may not guarantee more domestic production and jobs if the domestic value-added content of exports does not rise.

To address these issues and measure the participation and distribution of gains from GVCs, this paper uses value-added analyses based on harmonized world input-output tables, provided by the WTO-OECD.

Foreign value added in GVCs is likely to measure only backward linkages of a country. To be linked into GVCs, a country's forward linkages are equally important as they measure the extent of domestic value added which enters exports of other countries.

This paper estimates backward linkages (foreign value-added in exports) and forward linkages (domestic value-added which enters other countries' exports) of each country and estimates the extent of countries' participation in GVCs in terms of its share in total value-added created by GVCs. The results show that the share of OECD countries is around $61 \%$ of total value-added in GVCs, while the share of BRICs countries is $14 \%$, that of NICs1(Chinese Taipei, Korea, and Singapore) and NICs2(China, Hong Kong, Malaysia, Philippines, and Thailand) is around 11\%, and the share of the rest of the developing and least developed countries in the world is $8 \%$ of total value-added in GVCs.

The participation of China and the US in GVCs is the highest (9\%) followed by Germany (8.7\%), France and Japan (4.5\%), South Korea and the UK (4\%). However, forward linkages (domestic value-added in other countries exports) are much stronger than backward linkages in case of Japan, US, and the UK. China and South Korea on the other hand, have stronger backward linkages as compared to forward linkages. The net value added gains is therefore negative for China and South Korea. Other developing countries, like India, Malaysia, the Philippines, Thailand, and Vietnam also show a ratio of less than one, indicating negative net gains in terms of value added from GVCs. Exporters of primary products or commodities have naturally higher forward 
linkages as compared to backward linkages as their exports are used as inputs in other countries' exports. However, these countries show low participation rates.

Examining the structure of gross exports in these countries, the importance of exports of consumption goods to final consumers is revealed. Most countries, except for South Korea and commodity exporters like Russia, have more than $50 \%$ of total domestic value-added entering exports for final demand in other countries. The share of consumption goods in total exports is $60 \%$ in the US, $52 \%$ in Japan, and $54 \%$ in China. The share of foreign value added by manufacturing sector in global gross exports is only $14 \%$, indicating that value added created through backward linkages in GVCs is only $14 \%$ of global exports which are likely to be shared among developing countries.

Studies have highlighted the shifting of profits from manufacturing activities to services like managing and marketing activities in GVCs. The higher competitiveness in services of OECD countries reflects the fact that for these countries, the contribution of services in value-added exports is almost $50 \%$. Out of this, $39 \%$ is sourced domestically while $11 \%$ is sourced from other countries. For BRICs countries, domestic value addition from services in their total value-added exports is only $33 \%$, of which $8 \%$ is sourced from other countries. In China, most of the value added in exports is created by the manufacturing sector and services contribute only $29 \%$ of total value added exports, of which $40 \%$ is imported from other countries. If competitiveness in services determines the distribution of profits in GVCs, developing countries stand little chance of raising their shares in GVCs.

GVCs tend to concentrate in high-tech industries, further minimizing the scope for developing countries to climb value-chains to increase their share in total incomes. The example of China shows that in high tech industries, higher participation in GVCs may not necessarily imply higher gains. Even if China is the largest exporter in the world in electrical and optical equipment, its domestic value-added comprises only $57 \%$ in its gross exports. Forward linkages are found to be much stronger in the US as compared to its backward linkages in industries like machinery, equipment, and chemical products.

The above analyses provide important policy insights. Export-led growth has been successful in many developing and least developed countries, especially in some sectors like textiles. This growth has generated employment and production linked gains, for example, textile industry in Bangladesh. Exports from a country with little valueaddition and high import-content, however, may not be able to generate substantive employment. The emphasis therefore should be on higher value-added exports and not merely on higher exports. 
South Korea and Germany are good examples of countries with high participation in GVCs, and rising exports to GDP ratios but falling domestic value-added in exports in 2009 over 2005. Japan experienced high GVCs participation, but a falling exports to GDP ratio and falling domestic value-added content in its exports. China has fared better. Although its exports to GDP ratio has declined during this period, its domestic value-added content in exports has risen. This can be attributed to strong policy interventions in China. Mexico also appears to have gained from its participation in GVCs. The US appears to be the only country which has high participation in GVCs, rising exports to GDP ratio, and increasing domestic value-added content in its exports. Country experiences show that linking into GVCs may not bring gains automatically. Trade-led growth is more complex than it seems.

Received 30 July 2013, Revised 10 March 2014, Accepted 25 March 2014

\section{References}

Athukorala and Nasir (2012), "Global Production Sharing and South-South Trade-", background paper of ECIDC, UNCTAD

Baldwin, Richard (2012), "Global Supply Chains: Why They Emerged, Why They Matter, and Where They Are Going", Working Paper, FGI-2012-1, Fung Global Institute

Chen, H., M. Kondratowicz and K.-M. Yi (2005), "Vertical Specialization and Three Facts About U.S. International Trade“, North American Journal of Economics and Finance, Vol. 16: 35-39.

Gereffi G. (1999a), "International trade and industrial upgrading in the apparelcommodity chain", Journal of International Economics, Vol. 48: 37-70.

Gereffi, G. (1999b), “A commodity chains framework for analyzing global industries", in Institute of Development Studies, 1999, "Background Notes for Workshop on Spreading the Gains from Globalization", www.ids.ac.uk/ids/global/conf/wkscf.htm

Gereffi, G and M. Korzeniewicz (eds.) (1994), "Commodity Chains and Global Capitalism”, 
London: Praeger.

Hummels, David \& Ishii, Jun \& Yi, Kei-Mu (2001), "The nature and growth of vertical specialization in world trade", Journal of International Economics, Elsevier, Vol. 54(1): 75-96, June

Kaplinsky, R (1998), “Globalization, Industrialization and Sustainable Growth: The Pursuit of the Nth Rent", IDS discussion paper, Vol 365

Kaplinsky, R.(2005), “Globalization, Poverty and Inequality: Between a Rockand a Hard Place", Cambridge: Policy Press.

Kaplinsky, R. and Fitter, R.(2004), "Technology and Globalization: Who Gains When Commodities are De-commoditized?", International Journal of Technology and Globalization, Vol. 1, No.1.

Kaplinsky, R \&, Morris M (2001), “A Handbook for Value Chain Research”, Institute of Development Studies, University of Sussex.

Kogut, B. (1985), "Designing global Strategies: Comparative and competitive ValueAdded Chains", Sloan Management Review, Vol. 26(4): 15-28.

Milberg, W., "Shifting Sources and Uses of Profits: Sustaining US Financialization with Global Value Chains", Schwartz Center for Economic Policy Analysis. The New School. SCEP Working Paper 2007-9.

Mitsuhashi, Keiju (2005), “The furniture value chain from Thailand to Japan: Upgrading and the roles of buyer", PhD thesis at the University of Sussex.

Mudambi, R. (2007), "Offshoring: economic geography and the multinational firm", Journal of International Business Studies, Vol 38, No.1.

Porter, M.E. (1985), “Competitive Advantage: Creating and Sustaining Superior Performance", New. York: The Free Press.

Schmitz H (2006), "Learning and Earning in Global Garment and Footwear Chains", The European Journal of Development Research, Vol.18, No.4: 546-571 